\title{
A New Diffusion-Inhibited Oxidation-Resistant Coating for Superalloys
}

Michael A. Gedwill, Thomas K. Glasgow, and Stanley R. Levine Lewis Research Center

Cleveland, Ohio

September 1981

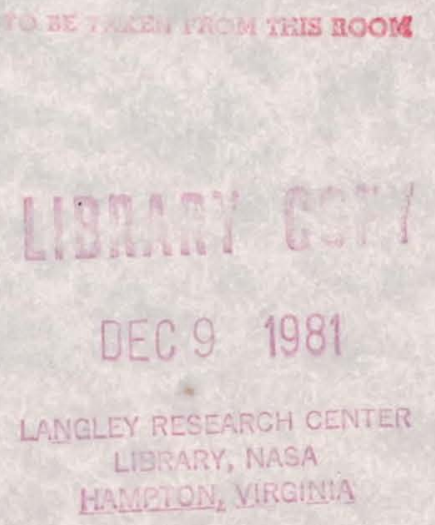




\title{
A NEW DIFFUSION-INHIBITED OXIDATION-RESISTANT
}

\section{COATING FOK SUPERALLOYS}

\author{
Michael A. Gedwill, Thomas K. Glasgow, \\ and Stanley R. Levine \\ National Aeronautics and Space Administration \\ Lewis Research Center \\ Cleveland, Onio 44135
}

\begin{abstract}
A new concept for enhanced protection of superalloys consists of adding an oxidation- and diffusion-resistant cermet layer between the superalloy and the outer oxidation resistant metallic alloy coating. Such a duplex coating was compared with a physical-vapor-deposited (PVD) NiCrAlY coating in cyclic oxidation at $1150^{\circ} \mathrm{C}$. The substrate alloy was MA 754 - an oxide-dispersionstrengthened superalloy that is difficult to coat. The duplex coating, applied by plasma spraying, outperformed the PVD coating on the basis of weight change and both macroscopic and metallographic observations.
\end{abstract}

\section{SUMMARY}

A new coating concept for the high-temperature protection of superalloys is presented. The concept consists of initially applying an oxidationresistant cermet (e.g., mechanically alloyed $\mathrm{NiCrAlY}+\mathrm{Y}_{2} \mathrm{O}_{3}$ powders) on the substrate and then applying a top coating of an oxidation-resistant alloy (e.g., a NiCrAly alloy). A method (but not the only one) for applying the duplex coating is arc-plasma spraying. The composition of the two coatings may be tailored to the substrate in order to reduce concentration gradients, and the top coating may be partly aluminized to improve its oxidation resistance.

To test this concept, the difficult-to-coat, oxide-dispersion-strengthened superalloy MA 754 was selected as the substrate. The performance of the diffusion-inhibited, plasma-sprayed duplex coating and a pnysically vapordeposited (PVD) NiCrAlY coating was evaluated in cyclic furnace and Mach 0.3 burner rig oxidation tests at $1150^{\circ} \mathrm{C}$. The duplex plasma-sprayed coating outperformed the PVD coating in both tests. Life of the duplex coating in the burner rig test was limited to about 200 hours because of localized wearout, as compared with less than 100 nours for the PVD coating. Post-test metallographic evaluations showed that, although the PVD coating was completely separated from the substrate after only 10 hours of furnace testing, the diffusion-innibited coatings were well bonded after 500 nours of furnace testing as well as after 300 hours of burner rig testing.

\section{INTRODUCTION}

In aavanced gas turbine engines, coatings are used to protect superalloy components from oxidation and hot corrosion. The useful lives of these components, however, are often limited by coating wearout at high temperatures. 
Wearout results from depletion of aluminum in the coating by aluminum oxide scale spallation and from dilution by interdiffusion with the substrate. The latter mechanism is often predominant at temperatures of $1100^{\circ} \mathrm{C}$ and above (ref. 1). Inhibiting interdiffusion thus offers a means for significantly extending coating life. Many attempts to improve the diffusional stability of coatings have been made. One approach has been to interpose an alloy layer, thereby grading the aluminum concentration profile (refs. 2 and 3 ). In an alternative approach a refractory metal or alloy layer is interposed (refs. 4 to o). Neither of these approaches appeared to be successful for use at temperatures above $1100^{\circ} \mathrm{C}$. This report presents a new approach involving the interposition of a cermet layer between the metallic top coating and the substrate. This approach has recently become feasible as a result of developments in mechanical alloying (refs. 7 to 9) and low-pressure arc-plasma spraying (ref. 10) that permit fabrication of the cermet and the coating application, respectively.

To most effectively demonstrate the feasibility of this concept, an alloy that has a severe coating diffusional instability problem was selected for this study. Mechanically alloyed (MA), oxide-dispersion-strengthened (ODS) superalloys have the strength potential for thousands of nours of use at hotspot temperatures to $1200^{\circ} \mathrm{C}$ (refs. 8 and 9). Even though the endurance of some ODS alloys has been improved by coating processes that use either aluminide diffusion coatings, aluminum-bearing overlay coatings, or a combination of these, the coatings offer only interim, short-term solutions to the problem (refs. 11 to 14). The protection ability of these coatings rapidly degrades at hign temperatures, primarily because of diffusional instability between the coating and the ODS substrate. For example, results obtained in cyclic oxidation testing for 200 hours at $1150^{\circ} \mathrm{C}$ in a Macn 0.3 burner rig show that NiCrATY and aluminide coatings on ODS MA 755E offered, at best, only marginal protection (ref. 11). Post-test, cross-sectional metallographic analysis showed considerable porosity (Kirkendall voids), especially in the highactivity-processed aluminide coating specimens. Some porosity was observed only in the aluminide coating before testing. However, ODS alloys (and to a lesser extent the non-ODS superalloys) that contain minor amounts of aluminum ( $\leqslant 1$ wt \%) are either very difficult to coat or the coating life is very short. The tendency for Kirkendall void formation in UDS alloys during either d luminide coating (high and low activity processing) or subsequent exposure at nigh temperatures was shown to be greater for low-aluminum-content alloys (ref. 12). This porosity formation along the coating-substrate interface eventually leads to delamination and spalling of the coating.

At INASA Lewis various coatings on MA 754 and MA $6000 E$ are being evaluated in cyclic furnace and Mach 0.3 burner rig oxidation tests at $1150^{\circ} \mathrm{C}$ in order to gain a more complete understanding of coating - ODS alloy interactions and to identify promising new coating concepts. In this investigation the lowaluminum-content alloy MA 754 has proven to be far more difficult to protect than MA 6000E. Thus MA 754 was chosen as the substrate for demonstrating the feasibility of the diffusion-inhibited coating concept.

MATERIALS, APPARATUS, AND PROCEDURES

Specimens of MA 754 (table I) were coated with either NiCrAlY or NiCrATY plus NiCrAlY-Y $2 \mathrm{O}_{3}$ by arC plasma spraying or with NiCrAlY by electron beam 
PVD. The plasma-sprayed coatings were manually applied by using a specially designed Mach 2.0 gun with a $\mathrm{CO}_{2}$ shroud. The chemical analyses of the spray powders are given in table II. The target thicknesses were $0.12 \mathrm{~mm}$ for the single coatings and $0.06 \mathrm{~mm}$ for each base and top coating in the duplex coatings. Mechanically alloyed powders (refs. 6 to 8) were used for the plasmasprayed base coating on INA 754, $\mathrm{Ni}-13 \mathrm{Cr}-7 \mathrm{Al}-0.3 \mathrm{Y}-27 \mathrm{Y}_{2} \mathrm{O}_{3}$ for the furnace coupons ( 25.4 by 19.1 by $5.1 \mathrm{~mm}$ ), and $\mathrm{Ni}-16 \mathrm{Cr}-8 \mathrm{~A} 1-0.5 \mathrm{Y}-8 \mathrm{Y}_{2} \mathrm{O}_{3}$ for the burner rig Dars (12.7 mm diameter by $82.6 \mathrm{~mm}$ long - see ref. 3 for design and other dimensions). A ary-atomized $\mathrm{Ni}-18 \mathrm{Cr}-12 \mathrm{Al}-0.3 \mathrm{Y}$ alloy powder, however, was used in applying the plasma-sprayed top coating. After spraying, the specimens were glass-bead peened and then heat treated at $1080^{\circ} \mathrm{C}$ for 4 nours in argon. The microstructure of a plasma-sprayed NiCrAlY plus NiCrATY$\mathrm{Y}_{2} \mathrm{O}_{3}$ cermet coating on MA 754 is shown in figure 1(a).

The PVD NiCrATY coating (Ni-19Cr-11A1-0.45Y), which is a commercial coating used on many current turbine blades and vanes, was applied to a target thickness of $0.12 \mathrm{~mm}$ by a coating vendor. After coating, the specimens were glass-Dead peened and subsequently heat treated by the vendor at $1080^{\circ} \mathrm{C}$ for 4 nours in vacuum. A PVD NiCrAlY coating on MA 754 is shown in figure 1(b).

The coatings were evaluated in cyclic furnace and Mach 0.3 burner rig oxidation tests at $1150^{\circ} \mathrm{C}$. The procedures and apparatus used in these tests are fully described in references 15 and 16 . Weight changes were recorded during testing and post-test visual, X-ray diffraction (XRU), and cross-sectional metallographic analyses were performed.

\section{RESULTS AND DISCUSSION}

\section{As-Deposited Coatings}

Pretest XRD and metallographic analyses were performed on selected specimens. The XRD data shown in tables III and IV indicate that B-NiAI was a major phase only in the PVD coating; $\beta$ was not detected even as a minor phase in the plasma-sprayed coatings. The $M_{23} \mathrm{C}_{6}$ (minor) phase in the latter coatings is probably due to dissociation of the $\mathrm{CO}_{2}$ shroud gas and formation of $\mathrm{Cr}_{23} \mathrm{C}_{6}$ in the plasma arc during spraying. The $\mathrm{M}_{23} \mathrm{C}_{6}$ phase, detected as a major phase in the PVD coating, is believed to have formed during the postcoating vacuum heat treatment. XRD patterns obtained on recently coated specimens showed no evidence of $\mathrm{M}_{23} \mathrm{C}_{6}$ after PVD coating but indicated the presence of $\mathrm{M}_{23} \mathrm{C}_{6}$ as a major phase (strong pattern intensity) after the postcoating vacuum heat treatment. The effect of $\mathrm{M}_{23} \mathrm{C}_{6}$ on coating performance nas not been studied. Carbide formation, however, may be desirable on carbide-type directional eutectic alloys. It is suggested that, in the future, inert environments and environmental monitoring be employed during coating and postcoating heat treatments.

Cross-sectional photomicrographs of plasina-sprayed and PVD-coated MA 754 specimens are shown in figure 1 . Since the plasma-sprayed coatings (fig. 1(a)) were manually applied, considerable variation in coating thicknesses was noted in these specimens. The globular particles observed throughout the PVD coating (fig. I(b)) are believed to be $\mathrm{Cr}_{23} \mathrm{C}_{6}$. The dark areas on the substrate side of the bond interface in the PVD-coated MA 754 are areas of porosity. It is believed that this porosity occurred primarily during the postcoating heat treatment as a result of interdiffusion (i.e., nickel diffused 
faster into the coating than aluminum into the substrate). This porosity, however, has not been observed in PVU-NiCrAlY-coated MA 755E (ref. 11) and MA 6000 ( $\mathrm{fig} .2$ ) before exposure at temperatures of $1100^{\circ} \mathrm{C}$ or higher. It is felt that this absence of porosity in MA $755 \mathrm{E}$ and MA $6000 \mathrm{E}$ is due primarily to their higher aluminum concentration and perhaps secondarily to their higher refractory metal content relative to MA 754 (table 1). This reasoning is analogous to that proposed in reference 4 with respect to aluminide coatings on OUS alloys. The plasma-spray-coated MA 754 coupon in figure 1(a), however, shows no comparable porosity. Electron microprobe (EMP) profiles of nickel, chromium, and aluminum across the coating-substrate interface indicated very little, if any, interdiffusion as compared with significant nickel and aluminum interdiffusion for the PVD-coated MA 754.

\section{Cyclic Furnace Oxidation}

The specific weight change results obtained on bare and coated MA 754 coupons in cyclic furnace oxidation at $1150^{\circ} \mathrm{C}$ are shown in figure 3 . After an initial weight gain, bare MA 754 experienced rapid losses in weight on subsequent cycling. In contrast, the PVD-NiCrAlY-coated MA 754 coupons showed weight gains through 100 hours of testing. The latter coupons were removed from further testing primarily because they exhibited severe blistering and apparent separation of the coating from the substrate. The duplex plasmaspray-coated coupons also showed weight gains, but only to about 75 to 100 hours and then lost weight thereafter. The plasma-sprayed coupons showed no evidence of blistering, even after 500 hours of testing. The weight losses experienced by these coupons are believed to be due mainly to coating distress, which began at the corner that had an attached support tab (fig. 4 ). Although the support tab (a low-aluminum-content NiCrAlY alloy) is required for PVD coating, the support tab on the plasma-sprayed coupons was used only to facilitate handling during spraying.

The XRD results shown in table III indicate that the $B-N i A$ l present in the PVO coating before testing decomposed in 100 hours or less at $1150^{\circ} \mathrm{C}$ as a result of spalling of the protective $\alpha-\mathrm{Al}_{2} \mathrm{O}_{3}$ oxide and/or coatingsubstrate interdiffusion. It is believed that the loss of the $\beta$ phase is primarily due to coating-substrate interdiffusion. The basis for this belief is that cross-sectional metallographic analysis of similarly coated coupons after only 10 oxidation cycles (fig. 5) or 10 hours of isothermal oxidation at $1150^{\circ} \mathrm{C}$ showed that what little $\beta-N i A l$ phase remained was located just below the oxide scale. No B-NiAl phase was detected in the coating near the substrate. If spalling of the protective $\alpha-\mathrm{Al}_{2} \mathrm{O}_{3}$ oxide had been the primary cause of the $\beta$ decomposition, the remaining $\beta$ phase would have been located at the coating-substrate interface. Post-test metallographic examination of the PVD coating after 100-hour cyclic oxidation showed no evidence of $B-N i A T$.

The superiority of the plasma-sprayed coating over the PVO coating is clearly shown in figures 5 and 6 , which show the coating separated from the substrate. In figure 5 the PVO coating completely separated from the substrate (except at the corners) after only 10 hours. It is believed that the separation was a result of interdiffusion between the coating and substrate that eventually forms a continuous network of Kirkendall voids along the bond interface. The plasma-sprayed duplex coating (fig. 6(b)), however, shows very little evidence of Kirkendall voids along the bond interface after 500 hours. 
This is attributed primarily to the cermet base coating, which acted as a diffusion inhibitor, and secondarily to the shallower concentration gradients. Eivp profiles of nickel, chromium, and aluminum across the coatingsubstrate interfaces of the specimens shown in figure 6 indicated very little interdiffusion in the plasma-spray-coated coupon after 500 hours as compared with that in the PVD-coated coupon after only 100 hours. Therefore the plasma-sprayed cermet interlayer appears to be an effective diffusion innibitor.

\section{Cyclic Burner Rig Oxidation}

Bare and coated MA 754 were oxidized at $1150^{\circ} \mathrm{C}$ for as long as 300 hours in a Mach 0.3 burner rig. The weight changes for all specimens are plotted in figure 7. Bare MA 754 experienced severe weight losses in less than 20 hours. The PVD-coated specimens, however, showed nonreproducible weight change behavior: One specimen showed a very high weignt gain after 100 hours; the otner exhibited very little weight change up to 100 hours but then began to lose weight rapidly. The behavior of the PVU-coated specimens is attriDuted to erratic blistering, separation, and cracking of the coating. In contrast, the behavior of the plasma-sprayed specimens was quite reproducible. Based on the time required to experience a significant rate of weight loss, the lives of the plasma-sprayed coatings were about 160 to 230 hours. However, the life of the duplex coating was only about 15 to 70 hours greater than that of the single plasma-sprayed coating. The duplex plasma-sprayed coating was only slightly diffusion inhibited with a cermet base coating containing about 8 wt $\% \mathrm{Y}_{2} \mathrm{O}_{3}$. Although the conclusion is not yet verified, furnace test results seem to show that a coating system containing about 27 wt $\% \mathrm{Y}_{2} \mathrm{O}_{3}$ in the base coating would perform significantly better. Furthermore aluminizing the top coating should be highly beneficial. XRD analyses (table IV) indicated tnat $\beta$-NiAl (a prerequisite for a good oxidation-resistant NiCrATY) was not present in the top coating before testing, probably as a result of aluminum depletion by oxidation during plasma spraying. Thus application by low-pressure (inert gas) plasma spraying snould improve coating performance (ref. 10).

Figure 8 shows coated MA 754 specimens after burner rig testing. Coating failures occurred either on or next to the back surface of the specimens, which were at a higher temperature in the burner flame than the front surface (ref. 17). The two PVD-coated specimens showed blistering and cracking of the coating (fig. 8(a)), which resulted in either a high or very low weight gain after I00-hour exposure, as discussed previously. Although the two plasmasprayed coatings (figs. 8(b) and (c)) were adherent for at least 300 hours, they started to fail by local wearout and then by catastrophic substrate attack after about 200 nours, but only in one area of each specimen. The incidence of coating wearout is in agreement with the gravimetric data in figure 7.

After burner rig testing, selected specimens were cross sectioned through the maximum attack zone and also near the bottom. The cross section near the bottom was considered to be typical of the "as-coated" condition. Photomicrographs of the coated specimens in the as-coated and as-tested conditions are shown in figure 9. A cross section of a PVD-coated MA 754 specimen after 100 hours of exposure at $1150^{\circ} \mathrm{C}$ (not presented in fig. y) showed blistering 
and separation of the coating from the substrate that was similar to that presented in figures 5 and $6(a)$, but more severe. Comparison of the microstructures in figures $9(a)$ and (b) indicates some loss of the two plasmasprayed coatings after 300 hours of exposure at $1150^{\circ} \mathrm{C}$. The duplex, slightly diffusion-inhibited, plasma-spray-coated microstructure after testing (fig. $y(b))$, however, shows slightly less porosity on the substrate side of the bond interface and within the substrate than does the single-layer, plasma-spraycoated specimen (fig. $9(a)$ ). This suggests that the cermet base coating (fig. g(b)) was somewhat instrumental in reducing coating-substrate interdiffusion during exposure in the burner flame and that higher volume fractions of ceramic phase, such as tested in the cyclic furnace tests, are preferred. As noted above, localized coating wearout and severe substrate attack (fig. $9(\mathrm{c})$ ) were observed on the plasma-spray-coated specimens.

\section{CONCLUUING REMARKS}

Coatings currently used to protect superalloys wear out by oxide scale spallation and by coating dilution as a result of interdiffusion with the substrate. A new coating concept involving the application of a duplex coating system wherein the inner layer is a diffusion-inhibiting cermet and the outer layer is a conventional overlay coating composition has been identified. Its performance was compared with that of a conventional physicalvapor-aeposited (PVD) NiCrAlY overlay coating on the difficult-to-coat, oxidedispersioned-strengthened (ODS) alloy MA 754 in cyclic furnace and Mach 0.3 burner rig oxidation at $1150^{\circ} \mathrm{C}$.

The new coating concept consists of initially coating the substrate with an intermediate cermet layer (base coating). In the present study the cermet was prepared by mechanical alloying. In that concept an oxidation- and hotcorrosion-resistant alloy (top coating) is then deposited on the cermet. To improve coating and bonding, the as-coated alloy is glass-bead peened and heat treated at $1080^{\circ} \mathrm{C}$ for 4 hours in an inert atmosphere. The metallic-element composition of the two coatings may be tailored to reduce the concentration gradients between the top coating and the substrate. Also, the top coating may be partly aluminized to improve its oxidation resistance. A method for applying the top and base coatings is arc-plasma spraying the coating powders in ambient air by using an inert-gas shroud and/or in a chamber with an inertgas or low-pressure environment. In the present work the sprayed NiCrAlY coatings were applied in air by using a Mach 2 gun with a $\mathrm{CO}_{2}$ shroud. These coatings were not aluminized before testing. For furnace and burner rig tests the sprayed base coatings were $\mathrm{Ni}-13 \mathrm{Cr}-7 \mathrm{Al}-0.3 \mathrm{Y}-27 \mathrm{Y}_{2} \mathrm{O}_{3}$ and $\mathrm{Ni}-16 \mathrm{Cr}-8 \mathrm{~A} 1-0.5 \mathrm{Y}-8 \mathrm{Y}_{2} \mathrm{O}_{3}$, respectively. The sprayed top coating for both tests was $\mathrm{Ni}-18 \mathrm{Cr}-12 \mathrm{Al}-0.3 \mathrm{Y}$.

In the furnace tests the duplex plasma-sprayed coating outperformed the PVO Ni-19Cr-11A1-0.45Y coating. The PVU coating separated from the MA 754 substrate in 10 hours or less as a result of interdiffusion between the coating and the substrate that led to the formation of Kirkendall voids. The plasma-spray coated MA 754 showed very little evidence of Kirkendal1 porosity after a 500-hour cyclic exposure. This was attributed primarily to the cermet base coating acting as a diffusion inhibitor.

The life of the duplex plasma-sprayed coating in the burner rig test was 1 imited to about 200 hours because of localized wearout of the coating. How- 
ever, in areas in which the coating was not completely worn out after 300 hours, the coating was adherent even though some Kirkendall porosity was observed in the MA 754. The PVD coating, however, blistered and cracked in less than 100 hours of cyclic exposure in the burner $r i g$.

The new coating concept was tried on OUS MA 754, which contains only 0.3 wt \% aluminum. The concept is also applicable to higher-aluminum-content OUS alloys (e.g., MA 6000E (4.5 wt \% Al)) and to non-OUS superalloys. Since coating-substrate interdiffusion is the primary contributor to the wearout of metallic protective coatings, this coating concept offers a means for significantly extending coating life. Furthermore opportunities for grading thermal expansion are available by judicious selection of the ceramic constituent and its concentration in the cermet layer. Thus this concept may also be applicable to low-thermal-expansion superalloys such as directionally solidified eutectics and powder-metallurgy alloys fabricated from rapidly solidified powders.

\section{REFERENCES}

1. Smialek, J. L.; and Lowe11, C. E.: Effects of Giffusion on Aluminum Uepletion and Degradation of NiAl Coatings. NASA TM X-68274, 1973.

2. Gedwill, M. A.; and Grisaffe, S. J.: Oxidation Resistant Claddings for Superalloys. Met. Eng. Q., vol. 12, no. 2, May 1972, pp. 55-61.

3. Gedwill, M. A.; and Grisaffe, S. J.: Aluminized Alloy Boosts Turbine Blade Life. Met. Prog., vol. 106, no. 3, Aug. 1974, pp. 66-68.

4. Wermuth, F. R.; and Stetson, A. R.: Alloyed Coatings for Dispersion Strengthened Al loys. (ROR-1686-3, Solar Div., International Harvester Co.; NASA Contract NAS3-14312.) NASA CR-120852, 1971.

5. Levinstein, M. A.: Enriched Aluminide Coatings for Dispersion Strengthened Nickel Materials. (General Electric Co.; NASA Contract NAS3-14314.) NASA CR-121250, 1973.

6. Young, S. G.; and Zellars, G. R.: A Feasibility Study of Uiffusion Barrier Between $\mathrm{Ni}-\mathrm{Cr}-\mathrm{Al}$ Coatings and Nickel-Based Eutectic Alloys. Thin Solid Films, vol. 53, 1978, pp. 241-250.

7. Benjamin, J. S.: Uispersion Strengthened Superalloys by Mechanical Alloying. Metal1. Trans., vol. 1, no. 10, 1970, pp. 2943-2951.

8. Merrick, H. F.; Curwick, L. R. R.; and Kim, Y. G.: Development of an Oxide-Dispersion Strengthened Turbine Blade Alloy by Mechanical Alloying. (International Nickel Co., Inc.; NASA Contract NAS3-19694.) NASA CR-135150, 1977.

9. Kim, Y. G.; and Merrick, H. F.: Characterization of an Oxide Dispersion Strengthened Superalloy, MA G000E, for Turbine Blade Applications. (Inco Research and Development Center; NASA Contract NAS3-20093.) NASA CR-159493, 1979.

10. Pennisi, F. J.; and Gupta, U. K.: Tailored Plasma Sprayed MCrATY Coatings for Aircraft Gas Turbine Applications. (PWA 5642-21, Pratt \& Whitney Aircraft; NASA Contract NAS3-21730.) NASA CR-165234, 1981.

11. Glasgow, T. K.; and Santoro, G. J.: Oxidation and Hot Corrosion of Coated and Bare Oxide Uispersion Strengthened Superalloy MA 755E. Accepted for Publication in Oxid. Met., 1981. 
12. Boone, D. H.; Crane, D. A.; and Whittle, U. P.: The Structure and Inter-Diffusional Degradation of Aluminide Coatings on Oxide Dispersion Strengthened Alloys. Submitted for Publication in Tnin Solid Films, 1981.

13. Gedwill, M. A.; and Grisaffe, S. J.: Evacuation of NiCrAl and FeCrAlY Claddings on TD-NiCr: Mach 1 Burner Rig Tests at $2100^{\circ} \mathrm{F}\left(1149^{\circ} \mathrm{C}\right)$. NASA TM X-52916, 1970.

14. Gedwil1, M. A.: Cyclic Oxidation of Coated Oxide Dispersion Strengthened (OUS) Alloys in High Velocity Gas Streams at $1100^{\circ} \mathrm{C}$. NASA TM-78877, 1978.

15. Barrett, C. A.; and Lowel1, C. E.: Comparison of Isothermal and Cyclic Oxidation Behavior of Twenty-Five Commercial Sheet Alloys at $1150^{\circ} \mathrm{C}$. NASA TN D-7615, 1974.

16. Gray, H. R.; and Sanders, W. A.: Effect of Thermal Cycling in a Mach 0.3 Burner Rig on Properties and Structure of Directionally Solidified $\gamma / \gamma^{\prime}$ - $\delta$ Eutectic. NASA TM X-3271, 1975.

17. Johnston, J.R.; and Ashbrook, R. L.: Oxidation and Thermal Fatigue Cracking of Nickel- and Cobalt-Base Alloys in a High Velocity Gas Stream. NASA TN D-5376, 1969. 
TABLE I. - NOMINAL COMPOSITION OF OXIDE-DISPERSION-STRENGTHENED

SUPERALLOYS

\begin{tabular}{|l|r|r|r|}
\hline \multirow{2}{*}{ Element } & \multicolumn{3}{|c|}{ Superalloy } \\
\cline { 2 - 4 } & MA 754 & MA 755E & MA 6000E \\
\cline { 2 - 4 } & \multicolumn{3}{|c|}{ Composition, wt $\%$} \\
\hline Cr & 20.3 & 15.0 & 15.0 \\
A 1 & .3 & 4.5 & 4.5 \\
W & ---- & 5.5 & 4.0 \\
Mio & --- & 3.5 & 2.0 \\
Ta & ---- & 2.5 & 2.0 \\
Ti & .4 & 3.0 & 2.5 \\
Y $_{2} U_{3}$ & .6 & 1.1 & 1.1 \\
Ni & Major & Major & Major \\
\hline
\end{tabular}


TABLE 11. - CHEMICAL ANALYSES OF PLASMA-SPRAYEU POWUERS ANU ELECTRON-BEAM, PHYSICAL-VAPOR-UEPOSITEU (PVD) COATING

\begin{tabular}{|c|c|c|c|c|}
\hline \multirow[t]{2}{*}{ Element } & \multicolumn{3}{|c|}{ Spray powders } & \multirow{2}{*}{$\begin{array}{c}\text { PVO Ni-19Cr-11A]-0.45Y } \\
\text { coatinga }\end{array}$} \\
\hline & $\mathrm{Ni}-18 \mathrm{Cr}-12 \mathrm{Al}-0.3 \mathrm{Y}$ & $\mathrm{Ni}-13 \mathrm{Cr}-7 \mathrm{Al}-0.3 \mathrm{Y}-27 \mathrm{Y}_{2} \mathrm{O}_{3}$ & $\mathrm{Ni}-16 \mathrm{Cr}-8 \mathrm{Al}-0.5 \mathrm{Y}-8 \mathrm{Y}_{2} \mathrm{O}_{3}$ & \\
\hline $\mathrm{Ni}$ & Major & Major & Major & Major \\
\hline $\mathrm{Cr}$ & 18.0 & 13.16 & 16.20 & 15.6 to 21.8 \\
\hline Al & 12.4 & 6.60 & 8.21 & 10.5 to 10.8 \\
\hline$\hat{y}$ & .29 & 21.38 & 6.70 & .43 to .47 \\
\hline$B$ & .002 & (c) & $<.01$ & (b) \\
\hline C & .018 & .089 & .085 & \\
\hline $\mathrm{Ca}$ & $<.001$ & (c) & $<.01$ & \\
\hline Co & .19 & $<.01$ & .035 & \\
\hline $\mathrm{Cu}$ & .009 & .008 & .027 & \\
\hline $\mathrm{Fe}$ & .075 & .28 & 1.04 & \\
\hline $\mathrm{Hf}$ & $<.01$ & (b) & $<.01$ & \\
\hline $\mathrm{Mg}$ & $<.001$ & (c) & $<.01$ & \\
\hline $\mathrm{Mn}$ & .002 & $<.01$ & .027 & \\
\hline Mio & $<.005$ & .011 & .045 & \\
\hline Nb & $<.01$ & (c) & (c) & \\
\hline $0_{2}$ & .011 & (b) & (u) & \\
\hline$p^{2}$ & $<.001$ & $<.001$ & $<.001$ & \\
\hline $\mathrm{S}$ & $<.001$ & .005 & .004 & \\
\hline $\mathrm{Si}$ & .048 & .015 & .035 & \\
\hline $\mathrm{Ta}$ & $<.05$ & ND & $<.05$ & \\
\hline$\lceil\mathrm{i}$ & $<.005$ & $<.01$ & .021 & \\
\hline V & $<.005$ & $<.01$ & .015 & \\
\hline$W$ & $<.01$ & (c) & (c) & \\
\hline $\mathrm{Zn}$ & $<.005$ & (c) & (c) & \\
\hline $\mathrm{Zr}$ & $<.01$ & (c) & (c) & $\dagger$ \\
\hline
\end{tabular}

ax-ray fluorescence of coating on witness tabs ( $r$ ange of analyses). bNot determined.

$c_{\text {Not }}$ detected. 
TABLE III. - PHASES IDENTIFIED BY X-RAY DIFFRACTION BEFORE AND AFTER CYCLIC FURNACE OXIDATION OF COATED MA 754 AT $1150^{\circ} \mathrm{C}$

\begin{tabular}{|c|c|c|}
\hline $\begin{array}{l}\text { Nominal coating composition, } \\
\text { wt } \%\end{array}$ & $\begin{array}{l}\text { Major phases } \\
\text { (relative } \\
\text { intensities)a }\end{array}$ & $\begin{array}{l}\text { Minor phases } \\
\text { (relative } \\
\text { intensities)a }\end{array}$ \\
\hline \multicolumn{3}{|c|}{ Before oxidation } \\
\hline $\begin{array}{l}\text { Plasma-sprayed } \mathrm{Ni}-18 \mathrm{Cr}-12 \mathrm{Al}- \\
0.3 \mathrm{Y} \text { (top) plus } \mathrm{Ni}-13 \mathrm{Cr}-7 \mathrm{Al}- \\
0.3 \mathrm{Y}-27 \mathrm{Y}_{2} \mathrm{O}_{3} \text { (base) }\end{array}$ & $\gamma$ or $\gamma / \gamma^{\prime}$ (VS) & $\begin{array}{l}M_{23} \mathrm{C}_{6}(\mathrm{~W}) \\
\alpha-\mathrm{A}_{2} \mathrm{O}_{3} \text { (VVW) }\end{array}$ \\
\hline PVD Ni-19Cr-11Al-0.45Y & $\begin{array}{l}\gamma \text { or } \gamma / \gamma^{\prime}(S) \\
\beta-N i A T(\text { iv) }) \\
M_{23} C_{6}(M)\end{array}$ & $\alpha-\mathrm{Al}_{2} \mathrm{O}_{3} \quad(W)$ \\
\hline \multicolumn{3}{|c|}{ After 100-hour oxidation b } \\
\hline $\begin{array}{l}\text { Plasma-sprayed } \mathrm{Ni}-18 \mathrm{Cr}-12 \mathrm{Al}- \\
0.3 \mathrm{Y} \text { (top plus } \mathrm{Ni}-13 \mathrm{Cr}-7 \mathrm{Al}- \\
0.3 \mathrm{Y}-27 \mathrm{Y}=\mathrm{O}_{3} \text { (base) }\end{array}$ & $\begin{array}{l}\gamma \text { or } \gamma / \gamma^{\prime}(S) \\
\alpha-\mathrm{A}_{2} \mathrm{O}_{3}(\mathrm{~S}) \\
\text { Spinel (M) } 0.810^{\mathrm{C}}\end{array}$ & ----- \\
\hline PVD Ni-19Cr-11Al-0.45Y & $\begin{array}{l}\gamma \text { or } \gamma / \gamma^{\prime}(S) \\
\alpha-\mathrm{Al}_{2} \mathrm{O}_{3}(S)\end{array}$ & \\
\hline
\end{tabular}

aRelative pattern intensities: VS, very strong; S, strong; $M$, moderate; $W$, weak; VVW, very very weak.

bcycles: $1 \mathrm{hr}$ at $1150^{\circ} \mathrm{C}$ and $20 \mathrm{~min}$ or more cooling.

CEstimated lattice spacing $a_{0}$ of spinel in nanometers $( \pm 0.05 \mathrm{nin})$.

dsame results after 500 hr of oxidation. 
TABLE IV. - PHASES IDENTIFIED BY X-RAY DIFFRACTION ON COATED MA 754 SPECIMENS BEFORE BURNER RIG TESTING

\begin{tabular}{|c|c|c|}
\hline $\begin{array}{l}\text { Nominal coating composition, } \\
\text { wt } \mathscr{\phi}\end{array}$ & $\begin{array}{l}\text { Major phases } \\
\text { (relative } \\
\text { intensities)a }\end{array}$ & $\begin{array}{l}\text { Minor phases } \\
\text { (relative } \\
\text { intensities)a }\end{array}$ \\
\hline PVD Ni-19Cr-11A1-0.45Y & $\begin{array}{l}\mathrm{M}_{23} \mathrm{C}_{6}(\mathrm{~S}) \\
B-\mathrm{NiAl}(\mathrm{M})\end{array}$ & $\begin{array}{l}\gamma \text { or } \gamma / \gamma^{\prime}(W) \\
\alpha-\mathrm{Al}_{2} \mathrm{O}_{3}(W)\end{array}$ \\
\hline $\begin{array}{l}\text { Plasma-sprayed } \mathrm{Ni}-18 \mathrm{Cr}- \\
12 \mathrm{~A} 1-0.3 \mathrm{Y}\end{array}$ & $\gamma$ or $\gamma / \gamma^{\prime}(S)$ & $\begin{array}{l}M_{23} C_{6}(W) \\
\alpha-A 1_{2}{ }_{3}(V W)\end{array}$ \\
\hline $\begin{array}{l}\text { Plasma-sprayed } \mathrm{Ni}-18 \mathrm{Cr}- \\
12 \mathrm{~A} 1-0.3 \mathrm{Y} \text { (top) plus } \\
\mathrm{Ni}-16 \mathrm{Cr}-8 \mathrm{~A} 1-0.5 \mathrm{Y}-8 \mathrm{Y}_{2} \mathrm{O}_{3} \\
\text { (base) }\end{array}$ & $\gamma$ or $\gamma / \gamma^{\prime}(S)$ & $\begin{array}{l}\mathrm{M}_{23} \mathrm{C}_{6}(\mathrm{~W}) \\
\alpha-\mathrm{A}]_{2} \mathrm{O}_{3}(W)\end{array}$ \\
\hline
\end{tabular}

dRelative pattern intensities: S, strong; $M$, moderate; $W$, weak; VW, very weak. 


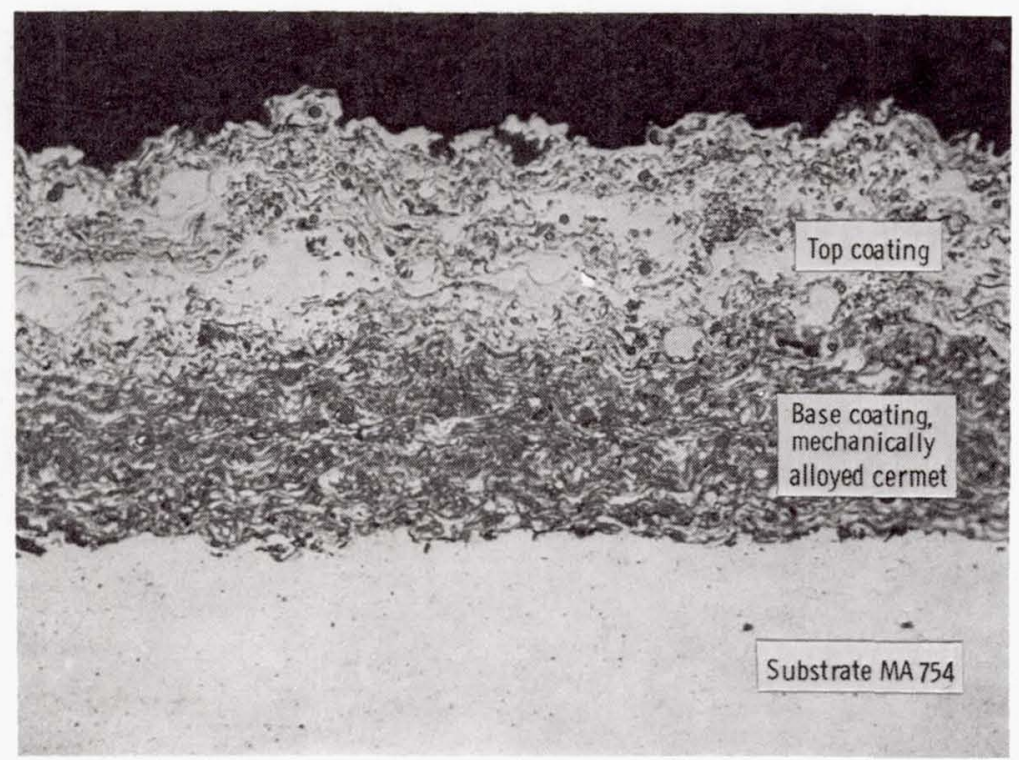

(a) Plasma-sprayed $\mathrm{Ni}-18 \mathrm{Cr}-12 \mathrm{Al}-0.3 \mathrm{Y}$ (top) and $\mathrm{Ni}-13 \mathrm{Cr}-7 \mathrm{Al}-0.3 \mathrm{Y}-27 \mathrm{Y}_{2} \mathrm{O}_{3}$ (base) coating heat treated at $1080^{\circ} \mathrm{C}$ for $4 \mathrm{hr}$ in argon.

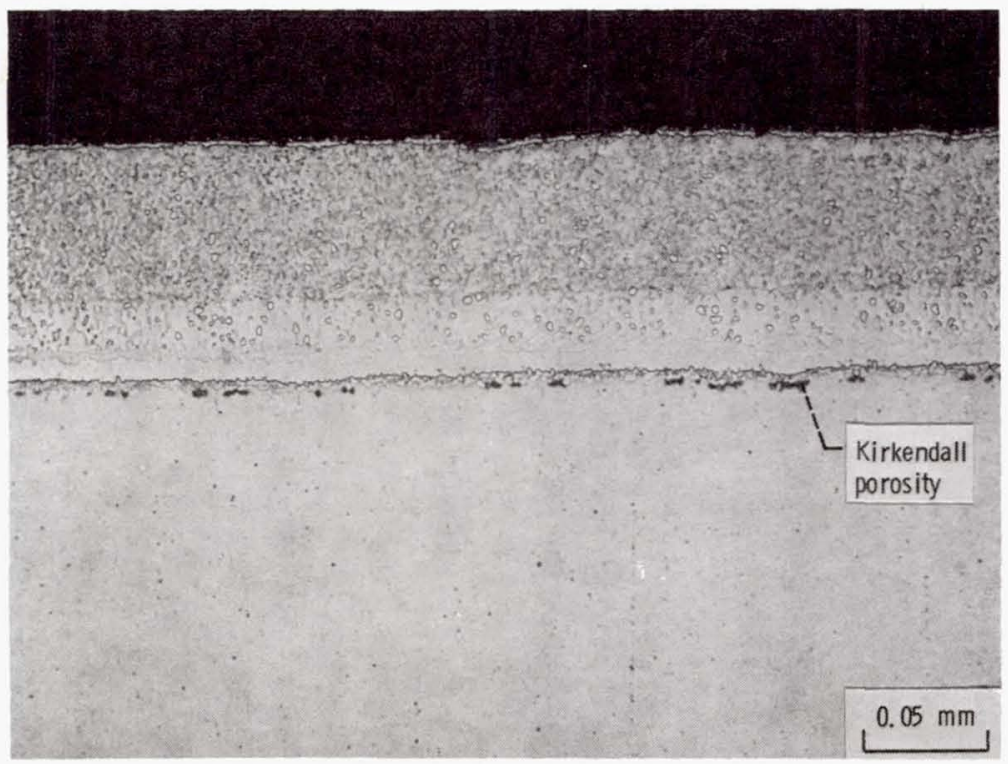

(b) Physical-vapor-deposited Ni-19 C r-11Al-0.45Y coating heat treated at $1080^{\circ} \mathrm{C}$ for $4 \mathrm{hr}$ in vacuum.

Figure 1. - Photomicrographs of as-coated MA 754. 


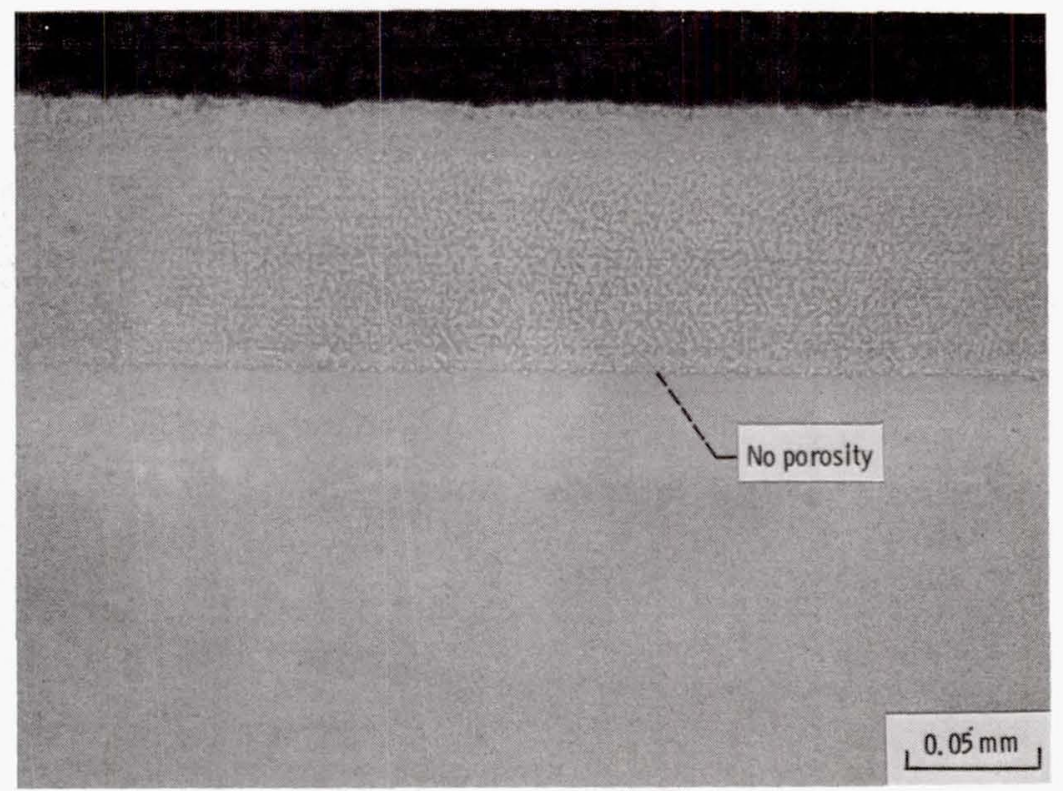

Figure 2. Photomicrograph of physical-vapor-deposited Ni-19 Cr-11Al-0. 45 Y-coated MA $6000 \mathrm{E}$ heated treated at $1080^{\circ} \mathrm{C}$ for $4 \mathrm{hr}$ in vacuum.

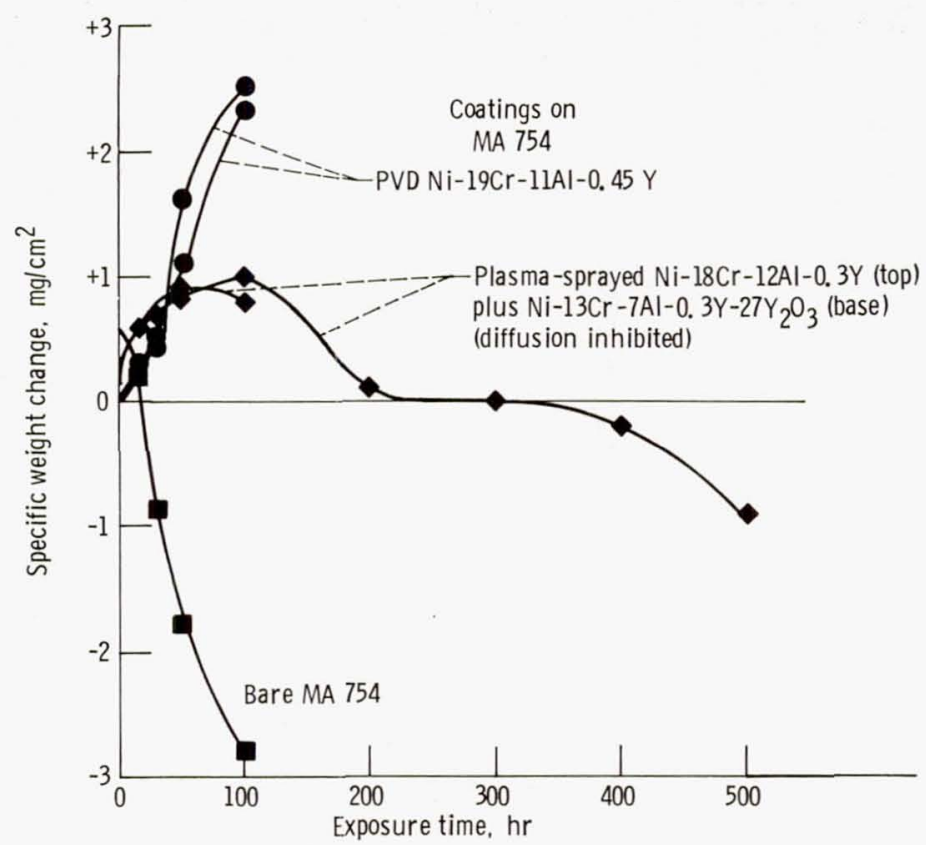

Figure 3. - Cyclic furnace oxidation of bare and coated Ma 754 at $1150^{\circ} \mathrm{C}$ using 1-hr cycles. 


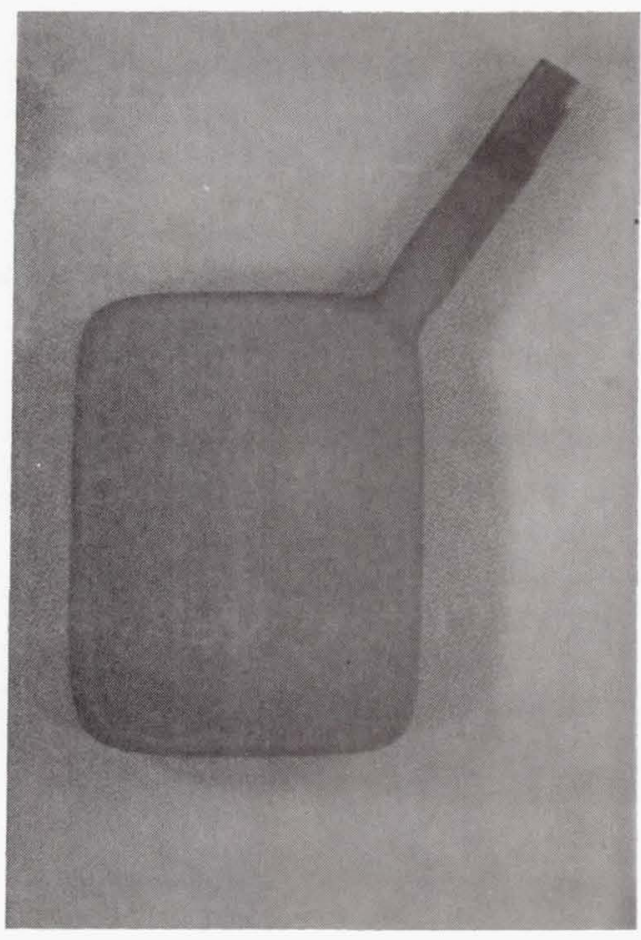

(a) As-coated coupon with support tab attached.

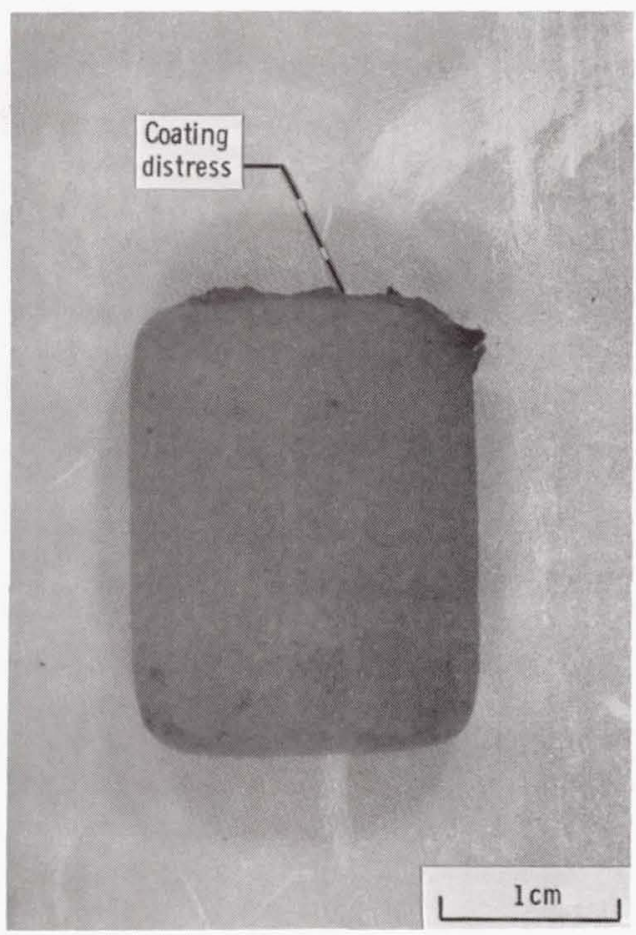

(b) Coated coupon after $500 \mathrm{hr}$ of cyclic (1-hr cycles) furnace oxidation at $1150^{\circ} \mathrm{C}$. Support tab removed before fu rnace oxidation.

Figure 4. - Plasma-spray-coated MA 754 coupons before and after cyclic furnace oxidation. Coating, Ni-18 $\mathrm{Cr}$ - $12 \mathrm{Al}-0.3 \mathrm{Y}$ plus $\mathrm{Ni}-13 \mathrm{Cr}-7 \mathrm{AI}-0.3 \mathrm{Y}-27 \mathrm{Y}_{2} \mathrm{O}_{3}$.

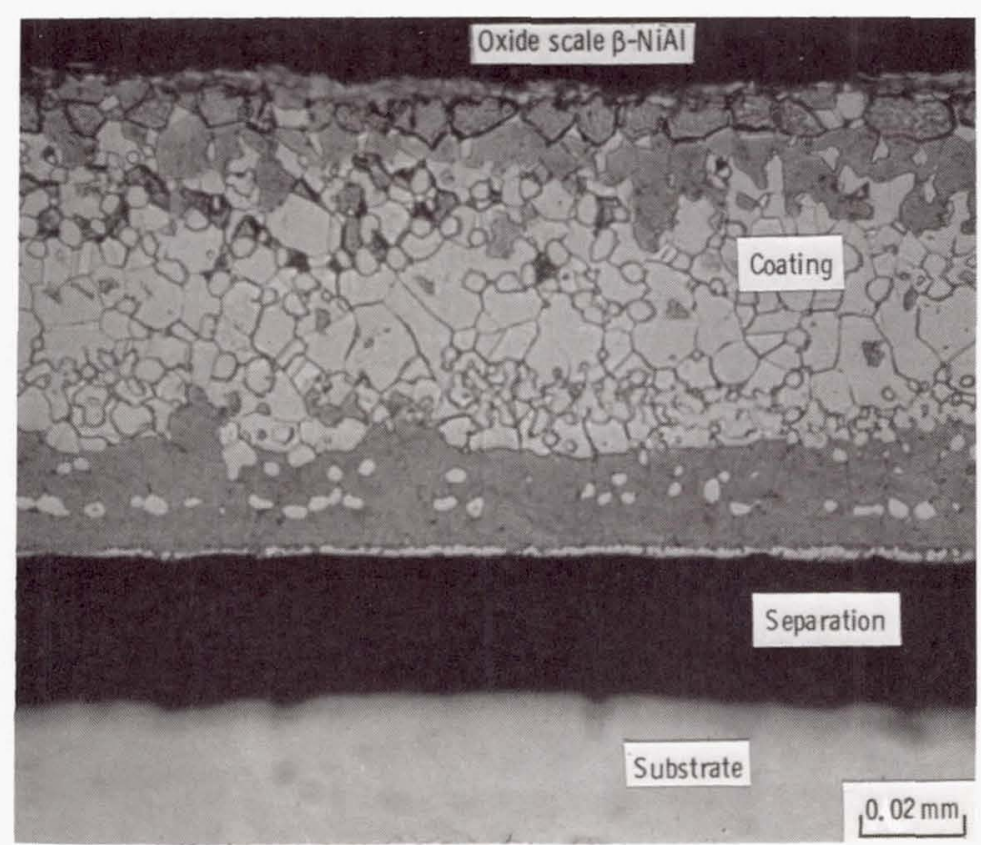

Figure 5. - Photomicrograph of physical-vapor-deposited Ni-19Cr-11Al-0. $45 \mathrm{Y}$ on MA 754 after ten 1-hr cycles of furnace oxidation at $1150^{\circ} \mathrm{C}$. Etched to reveal B-NiAl. 


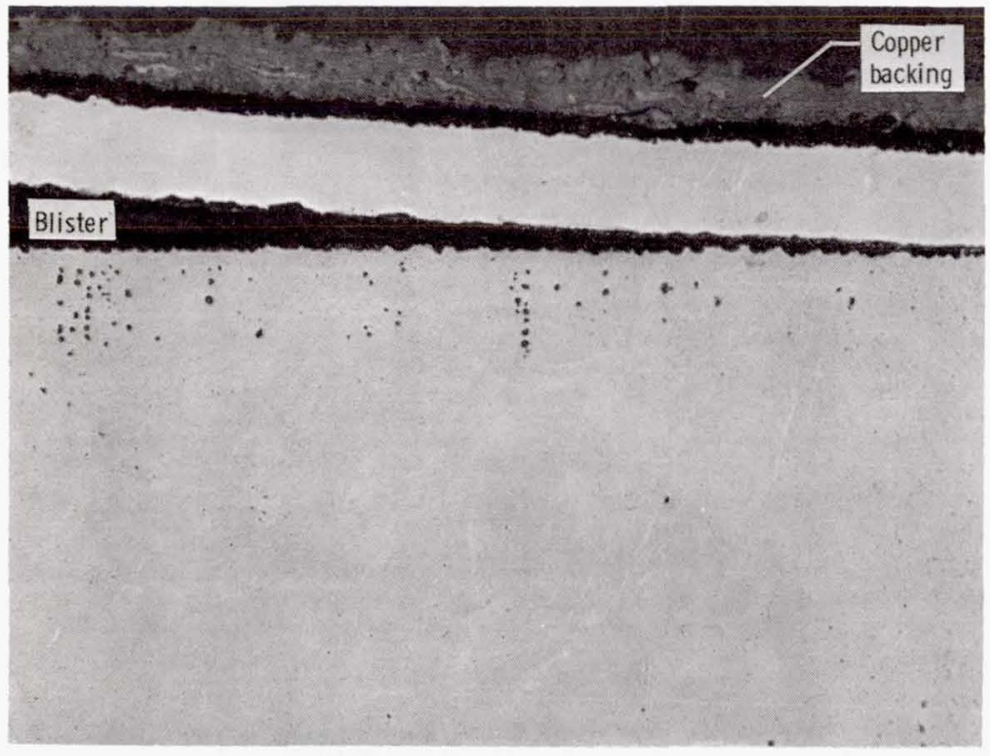

(a) Physical-vapor-deposited Ni-19 Cr-11Al-0. $45 \mathrm{Y}$ on MA 754 after $100 \mathrm{hr}$.

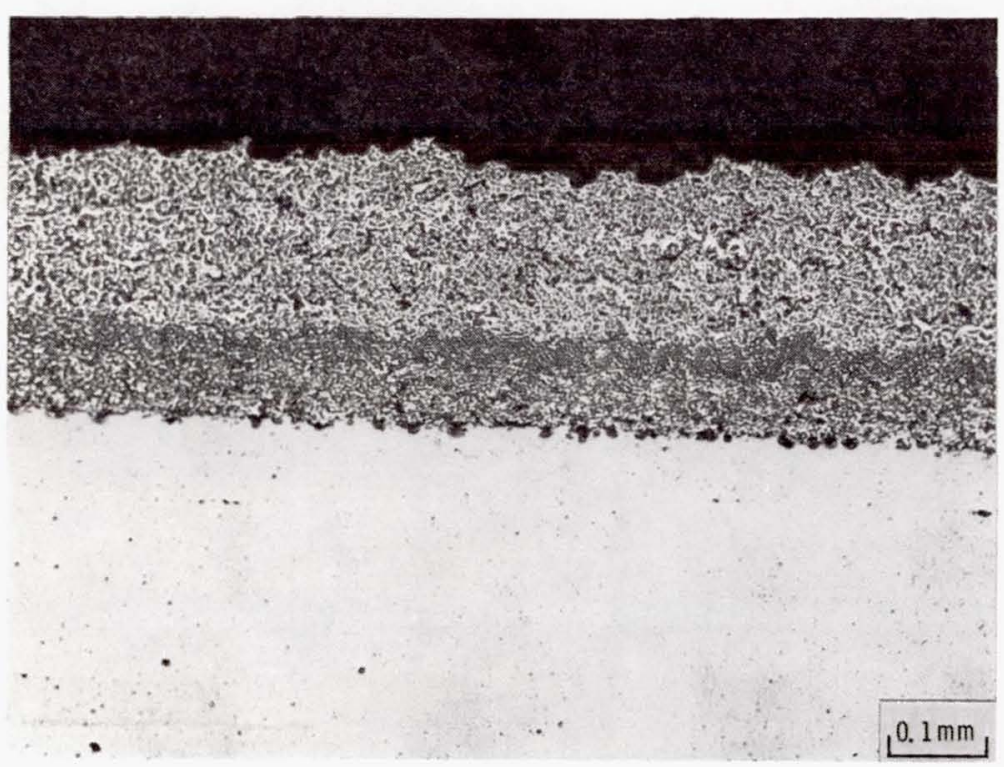

(b) Plasma-sprayed $\mathrm{Ni}-18 \mathrm{Cr}-12 \mathrm{Al}-0.3 \mathrm{Y}$ plus $\mathrm{Ni}-13 \mathrm{Cr}-7 \mathrm{Al}-0.3 \mathrm{Y}-27 \mathrm{Y}_{2} \mathrm{O}_{3}$ on $\mathrm{MA} 754$ after $500 \mathrm{hr}$.

Figure 6. - Photomicrographs of coated coupons tested in cyclic furnace oxidation at $1150^{\circ} \mathrm{C} ; 1$-hr cycles.

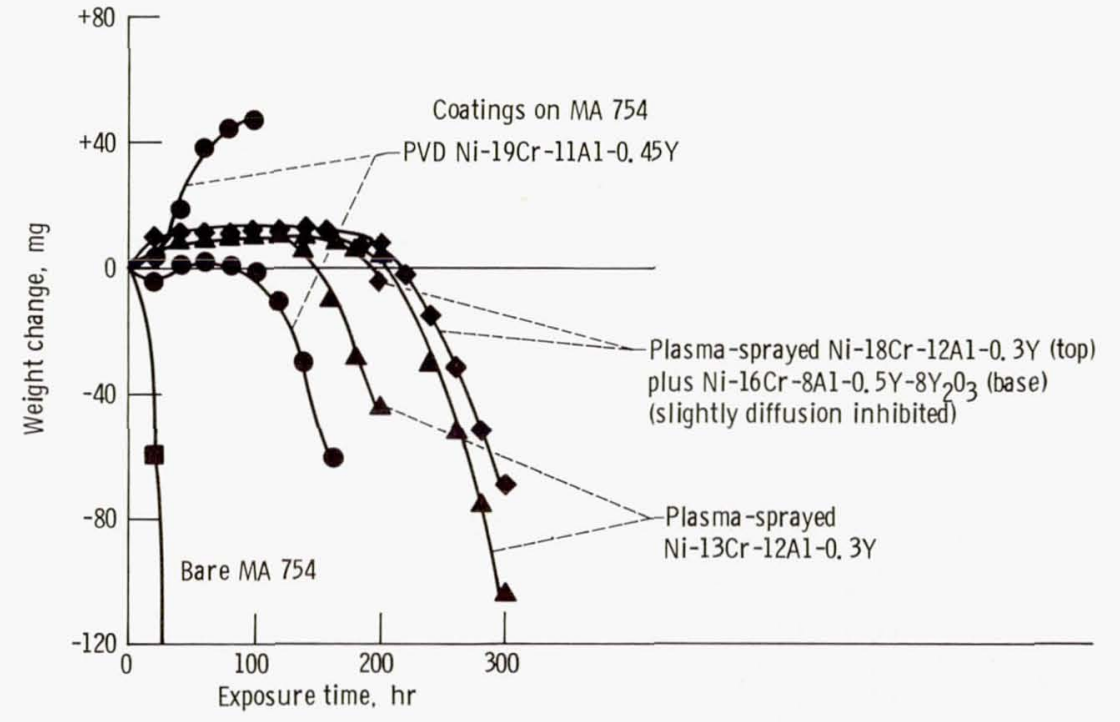

Figure 7. - Cyclic burner rig oxidation of bare and coated MA 754 at $1150^{\circ} \mathrm{C}$ and Mach 0.3 1-hr cycles. 


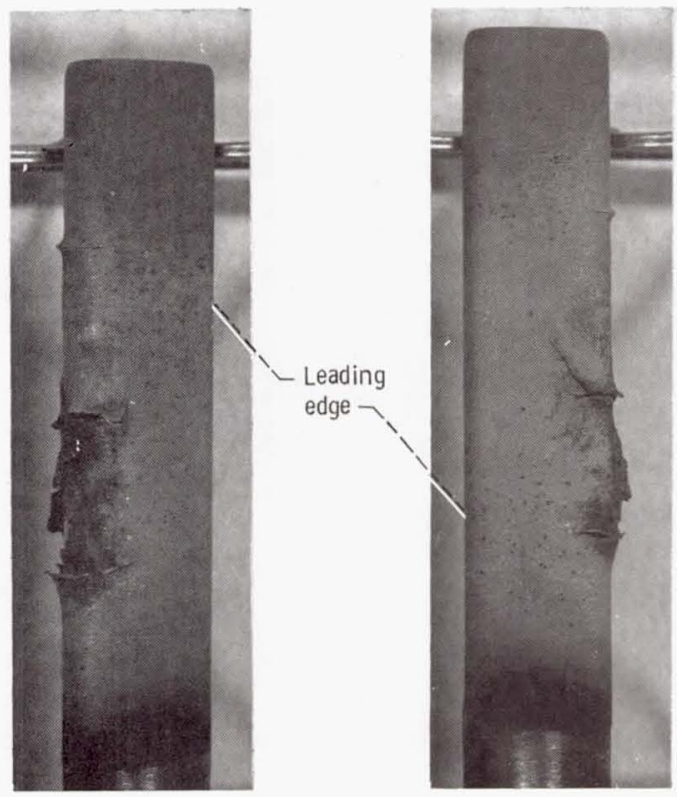

(a) Physical-vapor-deposited Ni-19CR-11Al-0. 45Y-coated MA 754 after $160 \mathrm{hr}$.

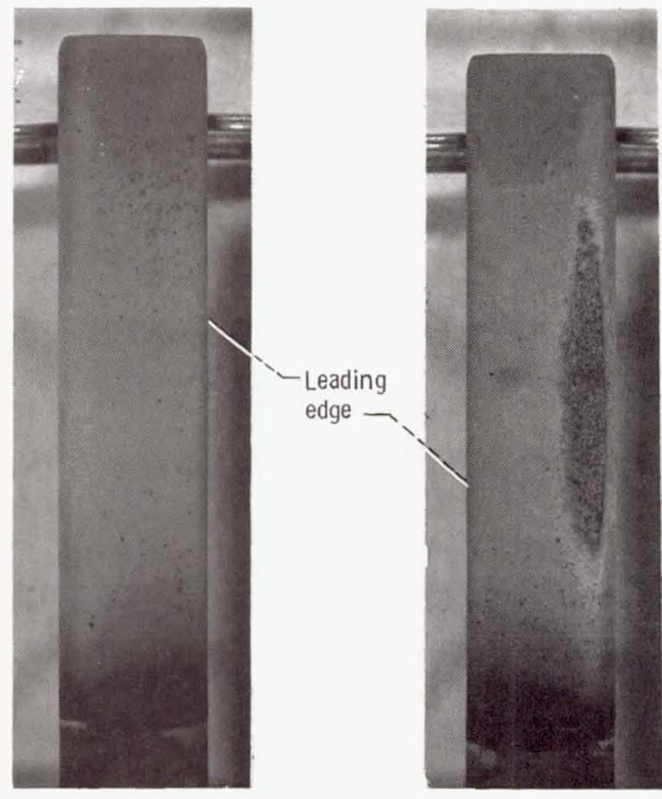

(b) Plasma-sprayed Ni-18Cr-12AI-0. 3Y-coated MA 754 after $300 \mathrm{hr}$.

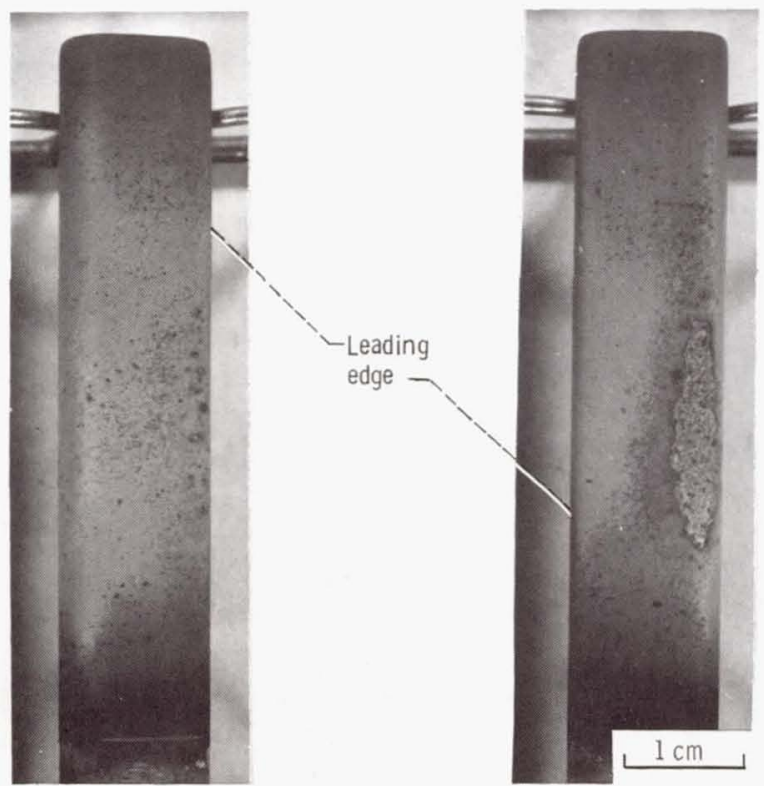

(c) Plasma-sprayed Ni-18Cr-12Al-0.3Y (top) plus Ni-16Cr-8Al-0.5Y-8Y $\mathrm{O}_{3}$ (base) coated MA 754 after $300 \mathrm{hr}$.

Figure 8. - Coated MA 754 after cyclic Mach 0.3 burner rig oxidation at $1150^{\circ} \mathrm{C}$; 1-hr cycles. 


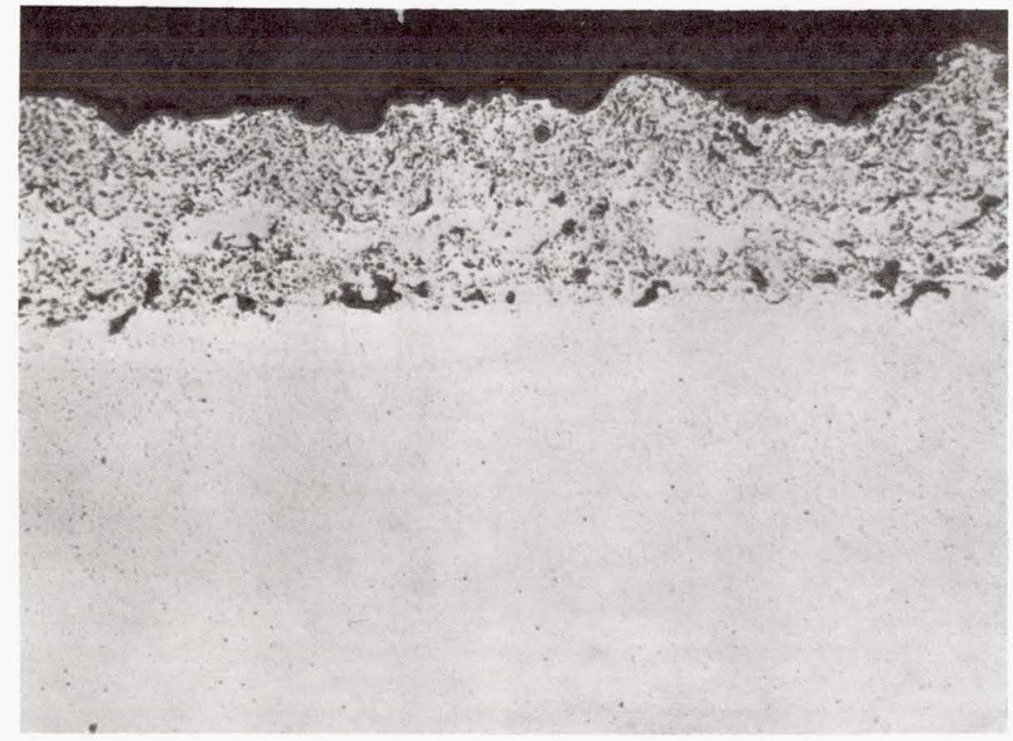

(a-1) As coated,

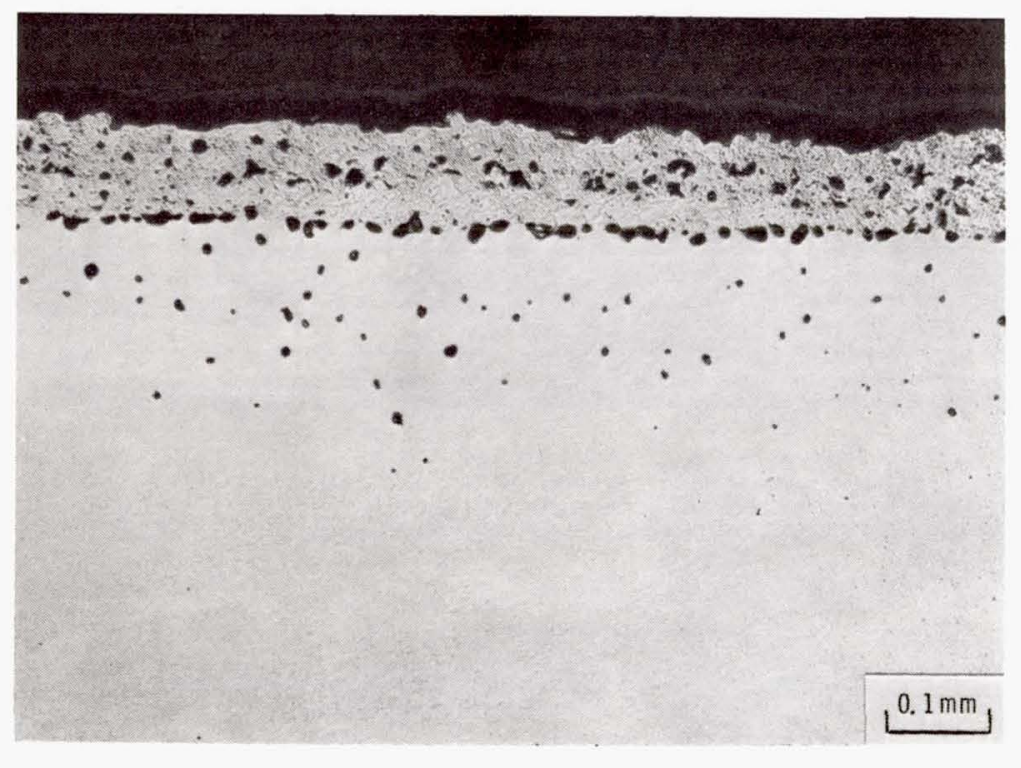

(a-2) As tested along one flat surface shown in figure 8 (b).

(a) $\mathrm{Ni}-18 \mathrm{Cr}-12 \mathrm{Al}-0.3 \mathrm{Y}$-coated MA 754 .

Figure 9. - Photomicrographs of plasma-spray-coated MA 754 before and after $300 \mathrm{hr}$ of Mach 0.3 burner rig oxidation at $1150^{\circ} \mathrm{C}$; $1-\mathrm{hr}$ cycles.

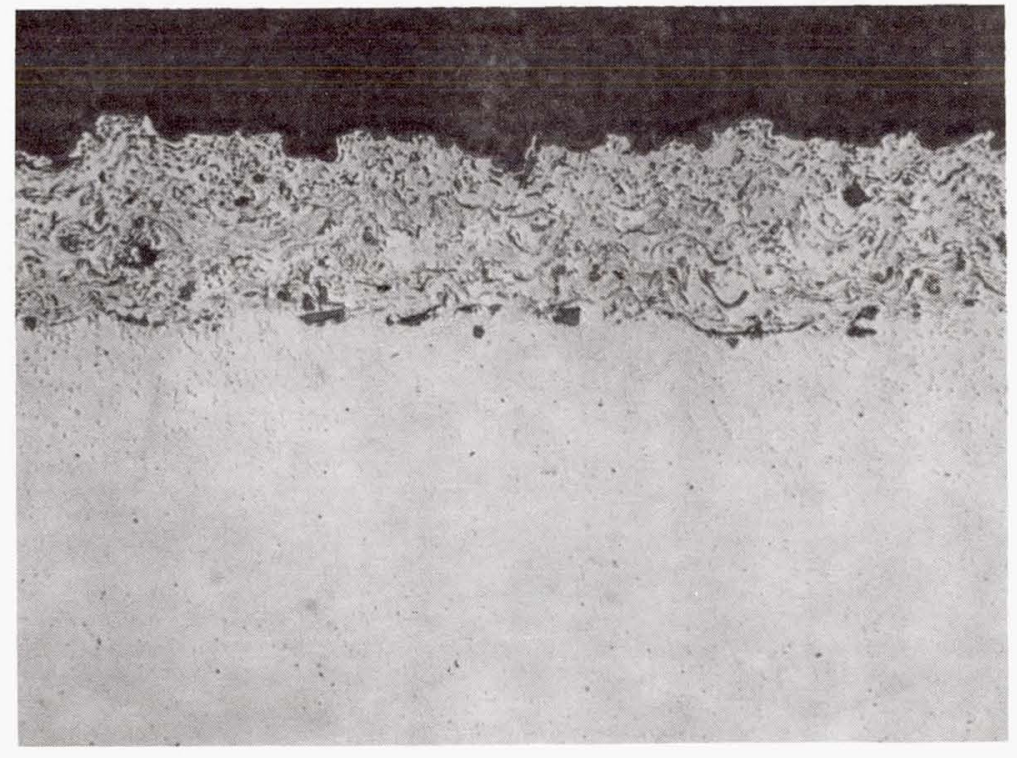

(b-1) As coated

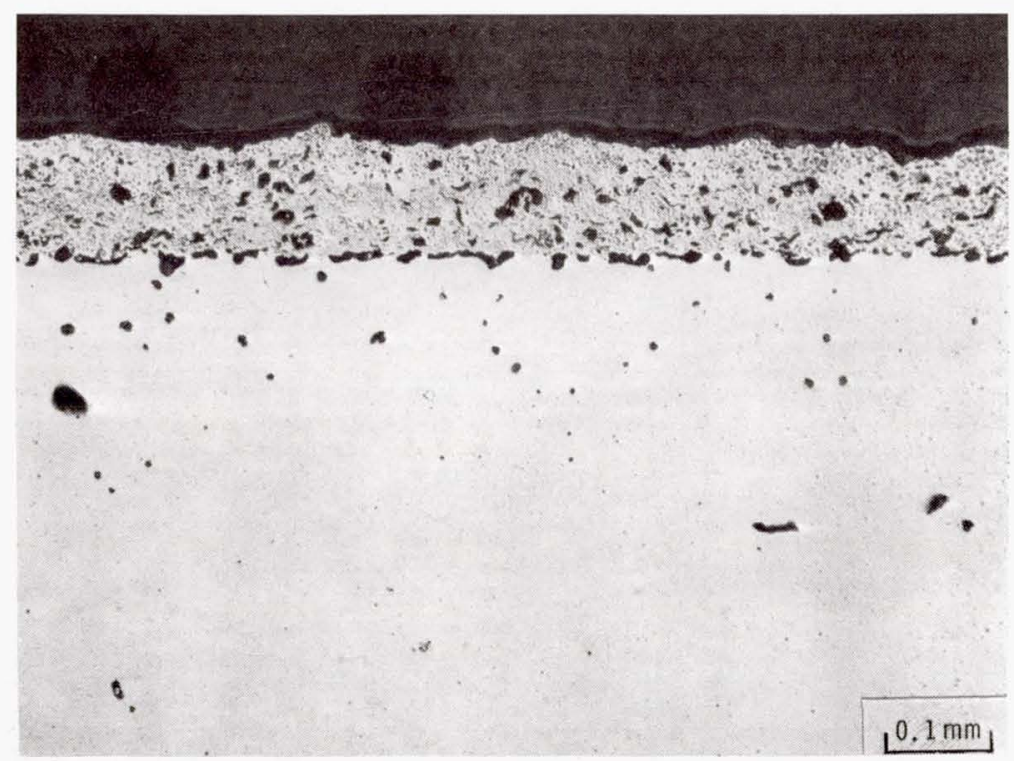

(b-2) As tested along one flat surface shown in figure 8 (C).

(b) Ni-18 Cr-12Al-0.3Y (top) plus Ni-16 Cr-8Al-0.5Y-8Y $2 \mathrm{O}_{3}$ (base) coated MA 754. Figure 9. - Continued. 


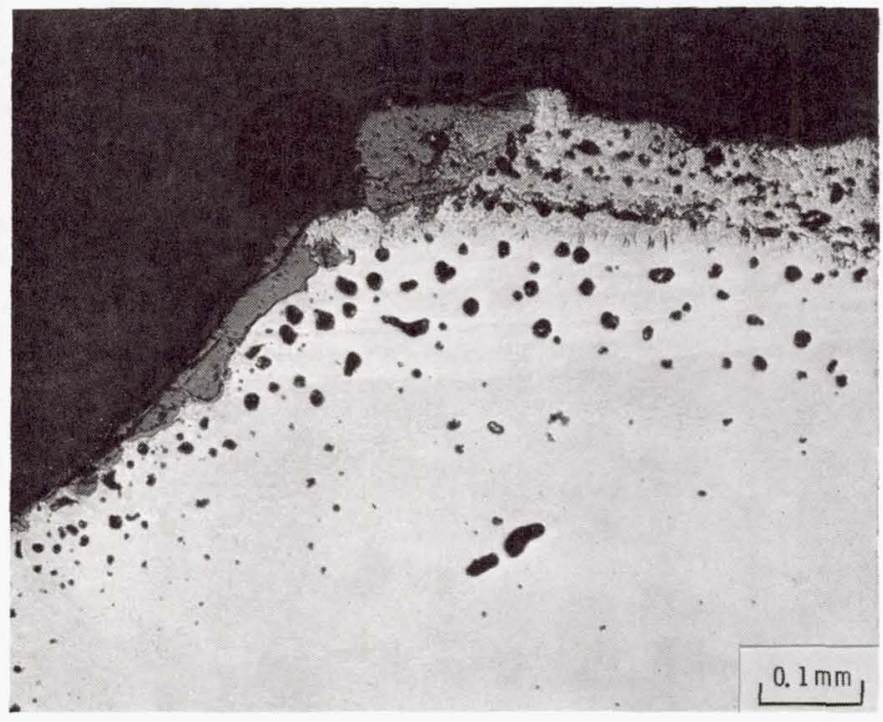

(c) $\mathrm{Ni}-18 \mathrm{Cr}-12 \mathrm{Al}-0.3 \mathrm{Y}$ (top) plus $\mathrm{Ni}-16 \mathrm{Cr}-8 \mathrm{Al}-0.5 \mathrm{Y}-8 \mathrm{Y} 2 \mathrm{O}_{3}$ (base) coated MA 754 as tested along flat surface near trailing edge (fig. $8(\mathrm{C})$ ), showing coating wearout.

Figure 9. - Concluded. 


\begin{tabular}{|c|c|c|c|c|c|}
\hline & $\begin{array}{l}\text { Report No. } \\
\text { NASA TM }-82687\end{array}$ & \multicolumn{2}{|c|}{ 2. Government Accession No. } & \multicolumn{2}{|c|}{ 3. Recipient's Catalog No. } \\
\hline & \multirow{2}{*}{\multicolumn{3}{|c|}{$\begin{array}{l}\text { Title and Subtitle } \\
\text { A NEW DIFFUSION-INHIBITED OXIDATION-RESISTANT } \\
\text { COATING FOR SUPERALLOYS }\end{array}$}} & \multicolumn{2}{|c|}{$\begin{array}{l}\text { 5. Report Date } \\
\text { August } 1981\end{array}$} \\
\hline & & & & \multicolumn{2}{|c|}{$\begin{array}{l}\text { 6. Performing Organization Code } \\
505-33-12\end{array}$} \\
\hline & \multicolumn{3}{|c|}{$\begin{array}{l}\text { Author(s) } \\
\text { Michael A. Gedwill, Thomas K. Glasgow, and Stanley R. Levine }\end{array}$} & \multicolumn{2}{|c|}{$\begin{array}{l}\text { 8. Performing Organization Report No. } \\
\text { E-968 }\end{array}$} \\
\hline \multirow{3}{*}{\multicolumn{4}{|c|}{$\begin{array}{l}\text { 9. Performing Organization Name and Address } \\
\text { National Aeronautics and Space Administration } \\
\text { Lewis Research Center } \\
\text { Cleveland, Ohio } 44135\end{array}$}} & \multicolumn{2}{|c|}{ 10. Work Unit No. } \\
\hline & & & & \multicolumn{2}{|c|}{ 11. Contract or Grant No. } \\
\hline & & & & \multirow{2}{*}{\multicolumn{2}{|c|}{$\begin{array}{l}\text { 13. Type of Report and Period Covered } \\
\text { Technical Memorandum }\end{array}$}} \\
\hline \multirow{2}{*}{12.} & \multirow{2}{*}{\multicolumn{3}{|c|}{$\begin{array}{l}\text { Sponsoring Agency Name and Address } \\
\text { National Aeronautics and Space Administration } \\
\text { Washington, D. C. } 20546\end{array}$}} & & \\
\hline & & & & \multicolumn{2}{|c|}{ 14. Sponsoring Agency Code } \\
\hline \multicolumn{6}{|c|}{ 15. Supplementary Notes } \\
\hline 16. & \multicolumn{5}{|c|}{$\begin{array}{l}\text { Abstract } \\
\text { A new concept for enhanced protection of superalloys consists of adding an oxidation- and } \\
\text { diffusion-resistant cermet layer between the superalloy and the outer oxidation-resistant metallic } \\
\text { alloy coating. Such a duplex coating was compared with a physical-vapor-deposited (PVD) } \\
\text { NiCrAlY coating in cyclic oxidation at } 1150^{\circ} \text { C. The substrate alloy was MA } 754 \text { - an oxide- } \\
\text { dispersion-strengthened superalloy that is difficult to coat. The duplex coating, applied by } \\
\text { plasma spraying, outperformed the PVD coating on the basis of weight change and both macro- } \\
\text { scopic and metallographic observations. }\end{array}$} \\
\hline 17. & \multicolumn{2}{|c|}{$\begin{array}{l}\text { Coatings; Cermet; Superalloys; Oxide disper- } \\
\text { sion strengthened alloys; Oxidation; Burner rig }\end{array}$} & \multicolumn{3}{|c|}{$\begin{array}{l}\text { 18. Distribution Statement } \\
\text { Unclassified - unlimited } \\
\text { STAR Category } 26\end{array}$} \\
\hline \multicolumn{2}{|r|}{$\begin{array}{l}\text { 19. Security Classif. (of this report) } \\
\text { Unclassified }\end{array}$} & \multicolumn{2}{|c|}{$\begin{array}{l}\text { 20. Security Classif. (of this page) } \\
\text { Unclassified }\end{array}$} & 21. No. of Pages & 22. Price $^{*}$ \\
\hline
\end{tabular}

* For sale by the National Technical Information Service, Springfield, Virginia 22161 
National Aeronautics and Space Administration

Washington, D.C.

20546

Official Business

Penalty for Private Use, $\$ 300$
SPECIAL FOURTH CLASS MAIL BOOK

Postage and Fees Paid National Aeronautics and Space Administration NASA -451

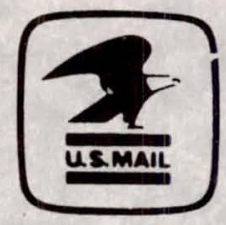

\section{N/SA}

If Undeliverable (Section $15 \%$ Postal Manual) 1\%o Not Return 